\title{
6. WHAT DOES IT MEAN TO BECOME A CHURCH MINISTER?
}

\author{
Life History and Imaginations of Future
}

\section{INTRODUCTION}

In the following, I will show how the psychosocietal approach has contributed to the interpretations of the qualitative interviews in my $\mathrm{PhD}$ dissertation A lifelong and life-wide perspective on students of theology and their constructions of themselves as ministers (Finholt-Pedersen, 2018). Halfway through my PhD, I became familiar with the psychosocietal approach and the lifelong learning project at Roskilde University with its theoretical approach to understanding learning and professional identity; this eventually became the main theoretical perspective in the analysis and interpretation of the data in my dissertation (Salling Olesen, 2006, 2017; Laursen, Moos, Salling Olesen, \& Weber, 2012).

The psychosocietal approach theorizes professional identity development and learning as a process where new learning is always based on previous life experiences. Drawing on psychoanalytic interpretation of subjective experiences and cultural phenomena, where psychological dynamics are seen as produced by societal relations and representing an inner psychological modality of culture, the psychosocietal approach understands learning as taking place through the patterns of interpretations already established in the learning subject. In this perspective, learning is understood to be both biographically situated and taking place within the specific context of the learning subject (Salling Olesen, 2007).

In the following, I will show how this theoretical approach contributes to a multilayered interpretation of two of the interviewees in the dissertation, Aksel and Ingrid, and particularly how their constructions of themselves as church ministers may be interpreted in a life history perspective, understood as their subjective processing of cultural meaning and social conditions.

The starting point and focus of the interpretations was therefore the students' lifehistorical experiences, understood as their specific individual mediation of their social conditions and historical circumstances, generating the individual's subjectivity that unfolds itself in consciousness and engagement later in life (Salling Olesen, 2007). In order to achieve this, I carried out hermeneutic interpretations of the students' life history narratives, guided by the conceptual framework of psychoanalysis and knowledge of the societal, historical and cultural contexts of these students. 
The aim of this chapter is to demonstrate how the psychosocietal approach to interpreting students' subjectivity, both on an individual and a societal level, enhances understanding of their learning development (Salling Olesen, 2007).

\section{BACKGROUND TO THE PROJECT}

Initially this $\mathrm{PhD}$ was planned as an inter-disciplinary project involving psychology and professional ethics. I was particularly interested in studying how the development of virtues for working life takes place in students of law and theology during their education. Twelve students of theology were interviewed three times over a period of about 15 months. The students of theology were students in the three schools educating Lutheran ministers in Norway: the Norwegian School of Theology in Oslo, the Faculty of Theology at the University of Oslo and VID Specialized University, which has incorporated the School of Mission and Theology in Stavanger. Fifteen law students were interviewed, but due to the huge amount of data, these interviews were omitted from the study.

The theology students certainly addressed many ethical topics regarding their future work in the interviews, but it was not their development of virtues that caught my attention as I started to analyse the interviews. The observations that struck me most were the students' reflections about their future ministry as a subjective conflict. The students were reflecting on themselves as future ministers in a life-historical perspective, addressing their future identity as a continuation of past experiences at home, at school, and in other contexts.

Another observation of note was that the students, in spite of their different lifehistorical experiences and backgrounds, articulated themselves in similar ways and within a specific theological discourse.

I also observed many inconsistencies in the students' articulations about themselves. These contradictions appeared far too significant to be ignored and I therefore wished to include them in the analysis and interpretation. I searched for new theoretical perspectives that could embrace them, instead of ignoring them. Individual interpretations and the virtue perspective seemed insufficient, and I started to use the psychosocietal approach as the main theoretical foundation for my analysis and interpretation of the data. The research question was reconstructed to include the different aspects of the students' socialization and subjectivity:

In which ways do life-historical processes of socialization play a part in theology students' development of a professional identity as a minister?

\section{AKSEL'S PERCEPTION OF BECOMING A MINISTER IN A LIFE-HISTORICAL PERSPECTIVE}

I will demonstrate how the students' individual mediation of their social conditions and historical circumstances generated their individual subjectivity by presenting 
one of the main topics in the interviews with Aksel and my interpretations of it. A strong ambivalence and insecurity unfolds when Aksel reflects on himself as a future minister. On a referential level, Aksel discusses the role of a minister in the context of the historical role and the general conceptions of the role in Norwegian society; however, my attention is focused on how Aksel's ambivalence and insecurity regarding the role of a minister may be interpreted in a life-historical perspective.

Aksel was raised in a religious family; his father is a Lutheran minister and he himself took part in church activities for children and young people. Aksel is not able to articulate clearly why he has decided to become a minister. When asked about his choice of career, he explains that what he now says about becoming a minister at the end of his studies must be understood as a rationalization of his reasons when he was 18. Another explanation is that as long as he, as the son of a minister, sees no need to distance himself from the Christian faith, joining the clergy is an obvious choice. Aksel has known many ministers since his childhood, many of his friends are ministers, he is happy to study theology and he has met several ministers during the practical component of his theology course; however, in spite of all this, his conceptions of being a minister are strikingly ambivalent and he appears to be deeply insecure about the role of a minister.

One of the conspicuous observations in the interviews with Aksel is his theoretical way of speaking about himself. He describes and explains himself through a theological discourse, positioning himself as a liberal theologian as opposed to "the pietists". In this discourse, pietists are constructed as abusing power and are associated with feelings and experiences. Liberal theologians such as Aksel are perceived as intellectual and as preaching about a loving and life-giving God. This polarization between pietists and Aksel himself as a liberal theologian is found in all the three interviews with Aksel.

Aksel's ambivalence and insecurity about the role of the clergy is expressed in his description of what he himself calls "the caricatured pastor", a pietistic pastor who abuses his professional power to present his own thoughts as God's thoughts. Aksel's description of the caricature of the pastor is contradictory. He describes a strongly problematic role as a member of the clergy, representing both the historical role and current conceptions of the role in Norway. At the same time, he affirms that this role does not really exist in today's society. Following this, when Aksel has firmly distanced himself from the caricatured pastoral role, he explores the pietistic pastor in more detail:

The pastor who has a suppressed sexual life and wants to tell the congregation how things should be, but he himself, inside he feels insecure and so on, and breaks down.

This pastor is described with distance and contempt. But more broadly, Aksel attributes to the clergy a huge responsibility for the people they meet, involving both their religious development and a general psychological foundation for life. He sees these demands as almost impossible to meet without hurting others. In spite 
of these perceptions of the role of a the clergy and its unrealistic demands, he also emphasizes that many people do have great trust in ministers on an individual level, which does not correspond to the general negative cultural conceptions of the clergy.

This ambivalent and insecure image of the clergy is related to Aksel's descriptions of himself as a minister; he is deeply concerned with the importance of being himself as a minister, but is not really able to convey what this means to him. Instead he expresses himself on a theoretical level, searching for theoretical concepts to settle this concern, but without success. At first, Aksel's concern about being himself as a minister appears to be general and obvious, but in a life-historical perspective on the interviews with him, it appears to have a deeper personal meaning.

Aksel's concern circles around the fear that his family will experience a split between his person as a minister and his person as a family member. He deals with this question in the framework of his wish to go to the pub; this has been one of Aksel's great concerns for years, which he discussed in all three interviews, and is also part of the polarization between pietists and liberals. As a young man in his home church youth group, Aksel wanted to go to the pub, but the pietists in the group argued that this would not be acceptable according to good Christian leadership standards. Now, years later, living in another city and not having the same group leadership responsibilities, Aksel could go to the pub. But still he does not "because that would make me feel like I was hiding away". In all three interviews with Aksel, he dwells upon this topic, but does not sort out if he can go to the pub or not, and expresses this as the fundamental question of whether he can be himself as a minister or whether he has to submit to the pietists' opinions about how he should live his life.

The liberal theologians' view of God, in contrast to that of the pietists, is also striking when Aksel speaks about his parents.

Well, er, the image of God, er, many researchers believe this is related to how your upbringing has been, and I had a great, nice upbringing with nice parents, and that, in a way, has given me security, and given me a good image of God, ... er, intellectually I like to think that it has to do with role models in the Faculty of Theology who have shown me an inclusive and loving God.

In Aksel's narrative, pietists are associated with feelings and experiences, unlike the intellectual liberal theologians. Being a liberal theologian, he does not make decisions based on experiences or strong feelings. As an intellectual, he reflects and makes decisions based on well thought out rational considerations. Further, pietists are associated with the abuse of power and an image of God as controlling, in contrast to the liberal view of an inclusive and loving God. Against this background, I found it notable that Aksel speaks about his meeting with the inclusive and loving God at the Faculty of Theology as a new experience compared to his childhood, while he also emphasizes that he received a good image of God at that time.

Aksel's description of his childhood gives the impression that he has not reflected much about it, and may be interpreted as containing an emotional simplification, expressed in the formulation nice and secure childhood. Aksel's descriptions of his 
childhood and of his experiences in the Faculty of Theology represent a break, not a continuation, in his narrative. First he assures me his childhood was nice and secure, and gave him a good image of God, but then he goes on to explain that it was in the Faculty of Theology he met the inclusive and loving God. This apparent lack of continuity between his childhood and his time in the Faculty of Theology seems to contradict his statement about his childhood as only nice and secure.

Considering Aksel's insecurity and ambivalence reflecting on the role of a minister in a life-historical perspective, the dichotomy between the pietists and the liberal theologians in Aksel's narrative seems to represent more than just different Christian traditions in Norwegian society. One possible interpretation is that this dichotomy can function as a defence system, giving him a language to handle difficult experiences. Pietists could then represent earlier experiences of power abuse now being articulated in Aksel's doubt as to whether he can be a minister or not. This theological discourse interpreted as a defence system could then represent his own personal insecurity, still unconscious to him but now expressing itself in a desire to tell others how to live, as the caricature of the pastor does, in order to protect himself from his own painful feelings of insecurity.

\section{INGRID'S PERCEPTIONS OF BECOMING A MINISTER IN A LIFE-HISTORICAL PERSPECTIVE}

Let me now turn to some of my observations in the interviews with Ingrid and her constructions of herself as a minister, interpreted in a life-historical perspective. Ingrid is well familiar with church life and many of her friends are also studying theology. As a future minister, Ingrid hopes to give people an experience of being valuable and loved by God. When Ingrid states her decision to become a minister, it appears to be the most obvious choice. However, when the interviews are examined more closely, her choice of becoming a minister seems both ambivalent and contradictory - and not so obvious after all.

When Ingrid talks about her decision to become a minister, I am struck by how haphazard her decision to study theology appears. She speaks as if she ended up studying theology by accident. Ingrid tells me about her original plans to spend a year as a volunteer in a Christian organization in northern Norway and then to take a master's degree in leadership studies. However, things did not work out as she had planned. She was unhappy in the North and after some difficult months, she decided to give it all up and leave the volunteer job. She describes this as a fundamental experience since this was her first time ever to give up on something. She had nowhere to stay, no job and had not been accepted for any courses that semester. Her friends told her she could still be enrolled in the School of Theology and she decided to do the first year of a bachelor's degree in theology and then move on to leadership studies.

On a referential level, it seems to be almost by accident that Ingrid is to become a minister, but in a life-historical perspective, some observations in the interviews 


\section{S. FINHOLT-PEDERSEN}

point in another direction. From early childhood, Ingrid was conscious of becoming a minister and stated this at the age of eight. She used to play being a minister and when she went to church with her parents, she paid careful attention to the minister, imagining how she would like to perform the tasks herself. Some of those ministers appeared very boring to her; she used to think it was important to have creative ministers, and as she liked to draw, she had the idea of incorporating drawing into her work as a minister.

Ambivalence also occurs as a striking theme in the case of Ingrid, when her decision to become a minister is examined more closely. In spite of her awareness about becoming a minister as a child, as a young adult, she is remarkably uncertain. She describes her insecurity about becoming a minister as a struggle between feelings and rationality. Her rationality tells her she does not like studying theology, but her feelings tell her theology is exciting and that she should continue studying the subject. Ingrid had difficulty in deciding whether to continue to do theology and become a minister and it was not until her father gave her his support that she decided to do so.

Ingrid's ambivalence about becoming a minister is articulated in terms of two significant themes in the interviews. As a minister, she imagines she will be able to express her feminine traits, to be a woman and to become a calm and peaceful person, not always the one who fights for what she believes is right, as she describes herself in the interviews. From an early age, Ingrid has paid attention to women ministers and she says that the fact that these women are ministers touched her in a special way. One of these female ministers is a friend of her parents she has known all her life. Even though this friend lived elsewhere and they did not go to her services, the fact that this woman was a minister, she tells me, was of great importance to her from an early age. Talking about the female ministers she has met as a young adult, Ingrid emphasizes these women's expression of their feminine traits as crucially important to her.

It's very much like, they have, that someone have given me the feedback, and that has meant a lot, er, yes, (silence) yes, about style, that you're dressed nicely, that's actually been very important to me, (laughter) that you're not like dressed in a rubbish bag, just because you're a girl and a minister, and don't have to cut off your hair, like, be tough and so on, I find that very nice, and it's meant a lot to me, "wow, you had that nice skirt" "yes, isn't that nice" "and that jewellery" that it may be fashionable and stylish and so on, I think it's fun, that you don't have to be a grey mouse, or, or, become masculine to be a minister, one of them I met, she was wearing black shoes and had a black skirt just above, right above the knees and nice tights, and a nice black top, her hair all over, and a lot of make-up, she was about 60, and in high heels, and a real lady, I think it was really great that someone really had the guts to be a real, a real woman, but that's maybe, not, more those kinds of things than theology or I think "you must do this and that" but it's more like, yes, yes, 
more the everyday life or obvious stuff maybe, mm, ... yes (silence) I think it's legitimiz- legitimizing my choice in a way, that I can be myself, and I can be a minister ...

The expression of her femininity and her desire to be a real woman is one of the main dynamics in Ingrid's reflections about her future as a minister. Furthermore, this is also a significant theme in her life history that she mentions as having to do with integrating her thoughts and emotions. It is through counselling sessions offered by the student chaplain at her school that Ingrid has become aware of this. As a young student of theology, she faced difficult existential questions like: who am I, why am I here and how have I become the person I am today, and therefore decided to start counselling sessions. Dealing with these questions, she has become aware of past experiences, particularly an experience of being harassed by one of her school teachers. Ingrid says she was an active and engaged child, but was told by the teacher: You must restrain yourself, and she considers this to be another fundamental experience with regard to her further development. She understands this experience to be the reason why she became cognitively strong and a person who stands up and fights for what she believes is right, at the expense of relating to her feelings.

In defending herself against the teacher's harassment, Ingrid took on a tomboy role to express strength and did not allow herself to show weakness or insecurity. In retrospect, she thinks being a tomboy appeared to be an easy solution to the situation she faced back then, giving her the opportunity to express her masculine qualities, but not the totality of the person she was. In this way, the tomboy role also shielded her from figuring out how she, as a girl, could integrate her feminine and masculine qualities. Now, as a young adult, Ingrid finds the tomboy role too limited. At the time of the interviews, she is searching for a way to integrate her femininity into a new role where she can both be a woman and express her abilities. In this life-historical perspective, Ingrid's constructions of herself as a minister appear to be a way of expanding the tomboy role that has now become too small for her.

\section{GENDER SUBJECTIVITY AND BECOMING A MINISTER}

The life history approach seeks to bridge the gap between the individual life course, the societal context of the individual's life that determines his/her experiences and the discourses framing that life and narrated by the individual (Salling Olesen, 2007). Ingrid's struggle can obviously be interpreted in the light of gender stereotypes and a social environment not allowing a girl to be autonomous and assertive. The tomboy is a temporary compromise, which must be resolved in a new way in the understanding of the role of a female minister. The psychoanalytic interpretation of cultural phenomena sees psychological dynamics as produced by societal relations and representing an inner psychological modality of culture, i.e. society plays a role on the inside, not only from the outside, of students' subjectivity (Salling Olesen, 2006). In this perspective on cultural phenomena, emotional and cognitive processes 
are seen as closely interwoven and as aspects of the subjective processing of cultural meaning and societal conditions. This can also be revealed in a close examination of male students' constructions of themselves as ministers in light of the social and implicit meanings associated with the role of a minister.

\section{THE SOCIAL AND IMPLICIT MEANINGS ASSOCIATED WITH THE ROLE OF A MINISTER}

The role of a minister exists within a socio-cultural context and is deeply involved in societal processes and structures. Historically, the clergy belonged to the aristocracy and the vocation is still associated with a male role. The relationship between the historical and present roles is not a linear process; the historical role was associated with formal and informal power, whereas in modern society, ministers are left without any kind of power. Some of the topics standing out in the interviews with the male students are related to their representations of the historical powerful clergy; the power they themselves will possess as ministers is an important issue for them. They express intense insecurity and ambivalence when thinking about themselves as powerful ministers.

The male students articulate an omnipotent role; as ministers they imagine that they will literally become almighty. They are fascinated by and fear the idea of being a minister. They position themselves in relation to the power associated with the role and seem to be trained to reflect on the powerful minister, being well aware of the illegitimacy in professional power abuse in today's society. I am struck by their understanding of power of the clergy as mainly negative, abused to repress others.

An important issue for them in connection with these concerns is the historical role of the clergy and the formal power and authority involved, especially the pietistic pastoral role, as represented by the caricature mentioned by Aksel. This pastor, according to Aksel, told others how to live, especially in the sexual domain, as a cover for his own insecurity. Furthermore, the male students speak about how the very role of the clergy may lead its members to harm others.

These perceptions of the power associated with the clergy may also be understood as articulations of the social meaning associated with the vocation, expressing something that transcends the actual role (Salling Olesen \& Weber, 2012, section 62). The meaning exists in the connection between the individual dynamics and the socially shared meaning. To identify this relationship in the context of the clergy, I feel that Aksel's caricature of a pastor serves as a good example.

The caricature of the pastor as a person with double standards presenting himself as a good moral person, telling others how to live to compensate for his own insecurity, and abusing his professional power to fulfil his personal needs, makes intuitive sense. Although we believe that this does not represent the truth about most pastors, the caricature may still exemplify a meaningful articulation of implicit and subtle meanings in our cultural perception of the role of the clergy - which the students also have. 
In the analysis and interpretation of the interviews with Aksel, I interpreted his uncertainty about the role of a minister as a misinterpretation of his personal insecurity expressed in his mention of the problem of the historical role of the pietist pastor. Interpreting the male students' uncertainty in light of the social and implicit meanings associated with the role of the clergy, understood as part of a cultural discourse, contributes to and expands the life-historical interpretation of their individual constructions of themselves as ministers. In the discourse in which these students understand themselves, the role of the pietistic pastor figures as a social representation of the authoritarian clergy. In this perspective, the social and implicit meanings associated with the role of the clergy may be interpreted to represent the male students' unconscious wishes and personal need for power, to compensate for their personal insecurity, producing intense ambivalence and possibly affecting their agency. Their role as ministers becomes important to them, as something they fear but also need, and it contains their unconscious wishes and needs.

\section{THE FEMALE STUDENTS OF THEOLOGY AND THEIR GENDER SUBJECTIVITY}

Reading the interviews with these theology students reveals a striking difference between male and female students in how they articulate their subjectivity in relation to their future vocation. The female students express their thoughts and experiences of the role of a minister as women, and in relation to how they have been perceived as girls in their childhood and as young women. The male students, by contrast, do not articulate their subjectivity in relation to their maleness. The topic of power is absent from the interviews with the women, but notably present in the interviews with the men. Based on these differences, it is interesting to reflect on Ingrid's constructions of herself as a minister, not only in her individual life perspective, but also in the way in which a societal perspective may expand and supplement the interpretations previously made in the life experience perspective.

Ingrid was brought up in a society where the perception of women's equality is well established. In Norwegian society, gender equality is considered an important value and women's possibility to become ministers may be seen as a contemporary expression of this. The first female minister, Ingrid Bjerkås, was ordained in 1961, and today there are many women in the clergy. In 2016, 406 of the 1273 ministers in the Norwegian Church were women. Of the 202 ministers under the age of 40 , 92 are women (Ragna Dalen, adviser in the Norwegian Church Council, e-mail $08 / 11 / 2017)$. However, the role of a minister is still perceived by many as a male role and Ingrid has made a challenging professional choice even today. In this broader societal perspective where ministers are associated with a male role while women are perceived as equal, I will reflect on how Ingrid's constructions of herself as a minister might be understood as an expression of her struggle to come out of the tomboy role.

In a material perspective, Ingrid's construction of herself as a minister may be considered an expression of a step out of female subordination. An approach 
that considers women equal to men takes for granted that women have been freed from subordination and have the opportunity to construct themselves as men do. In spite of the fact that Ingrid will take on a traditionally male role as a minister, her experiences and emotional conflicts bring into question the perception of gender equality in the society in which she was brought up.

From an early age, the female and male students are socialized differently, as I explored in the analysis of the interviews with the male students, who are socialized in perceptions of the powerful minister. Ingrid's ambivalence between being a woman and autonomous can be interpreted as an expression of women's socialization to subordination, articulated as a discourse where women are perceived as little, a child, dependent, quiet, passive and sweet. Girls' socialization to subordination has been strong in childhood and should be understood as part of their upbringing and repeated in their educational environment. Due to these cultural differences in girls' and boys' socialization, the female and male students' constructions of themselves as ministers are not comparable.

I mentioned above how Ingrid was expected by the teacher to restrain herself. This might be interpreted as an expression of the girl child's socialization to subordination as sweet, quiet and passive. As a girl, Ingrid had to give up her autonomy, and she took on a tomboy role to survive as a different girl. In a life-historical perspective, this was interpreted as a way of restraining her from expressing herself as a girl.

At the time of the interviews, Ingrid interprets the emotional conflicts she is struggling with as her private conflicts, articulating them within a life-historical framework. She understands the solution as lying in her ability to connect her feelings and thoughts and to come out of the tomboy role. This puts her in a state of mental conflict and she continues to struggle in the tomboy role that has become too small for her, while searching for a new role where she can integrate and embrace all her feelings, thoughts and qualities, and be a woman at the same time. It is within this societal situatedness that Ingrid as a young woman is trying to come out of the tomboy role and find a new role where she can be autonomous. In this societal perspective, Ingrid's constructions of herself as a minister might be interpreted as her search for a new role; taking on a male role associated with power may be seen as a search for a role where she can integrate being a woman and being autonomous. In this way, she is attempting to produce a new gender profile (Salling Olesen, 2005).

Ingrid struggles to grasp what it means to her to be an autonomous woman. She constructs herself as autonomous by taking on the role of a minister, but is left with no language to articulate what this means, other than talking about female ministers who appear as sweet, dressing in a feminine way and wearing make-up. She thus seems to remain in the ambivalence between being a woman and being autonomous.

Ingrid's way out of subordination appears to be more complex than taking on a male role. Ingrid's construction of herself as a minister may in a societal perspective be understood as a continuation of the existing structures of subordination of her childhood. Furthermore, she seems to be trying to come out of women's subordination within the structures of subordination. This places Ingrid in a psychodynamic sphere 
and in a societal contradiction: the perception of women's equality coupled with her socialization to subordination. She seeks autonomy within the social order she is socialized into, trying to construct herself as autonomous in a male role associated with autonomy.

\section{CONCLUSION}

These examples have shed light on how the psychosocietal approach provides an in-depth interpretation of the socialization of theology students, examining how one may theorize the dialectic relationship between the subject and the society in which the subject is constituted. This perspective reveals the complexity of learning processes, as well as possible barriers to learning and processes involved in the development of an identity as a minister. Based on the concepts of life history, subjectivity and experience, the psychosocietal approach offers an in-depth understanding of the processes of identity construction in students of theology. The life-historical perspective explores how one can theoretically connect individual students' integration of their previous experiences and orientations with the theological perspectives and understandings of their future profession they meet in their educational institutions. Theological education is placed within a lifelong perspective and studied in light of the opportunities it provides in all aspects of life, not just the clergy profession.

The life-historical socialization processes active in the development and establishment of a professional identity as a minister can be understood as different forces producing a dialectic result consisting of a particular historical subject in a particular social situation. These forces, which are active in individuals' constructions of themselves as ministers, are partly related to the individual life experience, which is socially constituted, and partly related to the specific situation in which the subject is active. This gives rise to a wide range of contradictory notions among the students about the role of the clergy and their ideas for the future, which are important for their orientation horizon and thus their development of life strategies.

The concept of life history derives from a critical theoretical tradition and opens up the interpretation of the data in light of how the socialization of theology students into the clergy is embedded in broader societal processes, such as the modernization of Norwegian society and the development of gender equality. An example of this is how female subordination should not be limited to an isolated challenge for theological schools or the Church, but must be understood in the wider societal context where these schools and the Church are situated. In this way, the psychosocietal approach provides insight into the subjective learning process as not limited to the institutional sphere of education, but also understood in the broader social context of theology students and theological institutions.

This critical perspective particularly illustrates the ways in which the educational programme promotes or constrains opportunities for the individual theology student to develop a professional identity as a future minister in modern Norwegian society. 
An example of this is the theological discourse where the positioning between pietists and liberals functions as a psychological defence reaction to the students' insecurity and fear of the role of the clergy and hinders them in expressing themselves in a new role as a minister.

\section{REFERENCES}

Finholt-Pedersen, S. M. (2018a). Hva er det å bli prest? Teologistudenter og subjektivitet - en kvalitativ analyse (PhD dissertation). Roskilde University.

Finholt-Pedersen, S. M. (2018b). Hva er det å bli prest? Teologistudenter og subjektivitet. Retrieved from https://video.ruc.dk/media/t/0_fmyll2no

Laursen, P. F., Moos, L., Salling Olesen, H., \& Weber, K. (2012). Professionalisering: en grundbog. Frederiksberg: Roskilde Universitetsforlag.

Salling Olesen, H. (2005). Work related learning, identity and culture. New work - new genders? New genders - new work? In A. Bron, E. Kurantowicz, H. Salling Olesen, \& L. West (Eds.), “Old” and "new" worlds of adult learning (pp. 25-39). Wagonowa: Wydawnictwo Naukowe.

Salling Olesen, H. (2006). Diskurs og erfaring. Eksempler fra lægeprofessionen. Nordisk Pedagogik, 26, $358-371$.

Salling Olesen, H. (2007). Theorizing learning in life history: A psycho-societal approach. Studies in the Education of Adults, 39(1), 38-53.

Salling Olesen, H. (2017). Learning and experience: A psycho-societal approach. In M. Milan, S. Webb, J. Holford, R. Waller, \& P. Jarvis (Eds.), The Palgrave international handbook on adult and lifelong education and learning (pp. 169-185). London: Palgrave Macmillan.

Salling Olesen, H., \& Weber, K. (2012). Socialization, language, and scenic understanding. Alfred Lorenzer's contribution to a psycho-societal methodology. Forum: Qualitative Social Research, 13(3). http://dx.doi.org/10.17169/fqs-13.3.1906 